\title{
EXPERIENCES OF IMMANENCE AND TRANSCENDENCE IN THE RELIGIOUS INFORMATION PRACTICES OF NEW KADAMPA BUDDHISTS
}

\section{Abstract / Résumé:}

\section{Introduction}

Reijo Savolainen, a leading scholar in the study of everyday life information practices and behaviours, notes that what defines everyday life information practices is the everyday itself, referring "to a set of attributes characterizing relatively stable and recurrent qualities of both work and free time activities. The most central attributes of everyday life are familiar, ordinary, and routine" (Savolainen, 2004, p. 1). Given the breadth provided by Savolainen's definition, there are several contexts and populations within the realm of "everyday life" that warrant further investigation. One such context is religion and spirituality. Religious information practices are information practices that consist of, or are related to religious beliefs and practices. This present study relies upon the interpretation of certain religious practices, particularly those that involve the use of written text (both printed and oral), as information practices. Understood within the everyday, these practices may include, for example, reading passages from scriptures, listening to an orally-delivered homily containing a religious message or investigating religious history on the Internet. These practices may be considered "everyday" as they comply with Savolainen's characteristics of being "familiar, ordinary, and routine". Indeed, the pursuit of a religious life is inseparable from the daily mental, verbal and physical actions that comprise it.

However, Emmons (1999) reports that it was early psychologist of religion Gordon Allport who was "the first to systematically distinguish religion as a means to an end and religion as a way of life" (p. 111). Religion possess a dual nature, one nature that is orientated to daily life and one that extends beyond it. Within the context of information practices then, scholars need to account for the seemingly dual nature of religious information behaviours, to account for both the everyday life information behaviours and those that are seemingly "beyond" everyday life such as using information to satisfy deep, existential longings for meaning and negotiating living within an unpredictable reality. It is no longer satisfactory to understand everyday life information behaviours and practices as confined to that which is "familiar, ordinary, and routine" but rather, it invites the question of whether "ELIS [everyday life information seeking] [is] sufficient in addressing information behavior within the context of the deeply meaningful, the unfamiliar, the extraordinary and profoundly emotional" (Clemens, 2015, p. 9).

\section{Literature Review}


Research already conducted within the realm of religious information practices is lacking an everyday life perspective. To date, the large majority of these studies conceptualize their participants (clergy and church leaders) as professionals who engage in work-related information practices to satisfy their roles as preachers, administrators and counsellors (e.g. Porcella, 1973; Phillips, 1992; Tanner, 1994; Wicks, 1999; Lambert, 2010). These studies are particularly focused on the resources employed by these professionals and the demographic and doctrinal variables that determine their selection. While still relying upon professional clergy person as an informant, studies by Roland (2007) and Michels $(2011,2012)$ focus instead on the clergy members and church leaders themselves, and not their resources, examining more closely their personal experiences of information practices in their churches. The above studies have also been confined to examining religious information practices within the context of Protestant Christianity. Only recently have studies such as Kari's investigation of information needs, seeking and outcomes of information concerning the paranormal (2001, 2009, 2011) and Saleh and Abu Bakar's (2013) study of Muslim clerics in Nigeria begun to examine contexts and populations outside of Christianity.

Thus, two significant gaps emerge from an examination of this literature. First, there is the aforementioned lack of studies that examine populations and contexts outside of Christianity, like Eastern religious traditions such as Buddhism. Second, within the realm of religious everyday life information seeking, there remains a paucity of examples. There is certainly more room for further studies of religious everyday life information that take new and fresh contexts that differ from those already studied, especially those that may investigate the "significant dimensions of information phenomena that may have been overlooked" (Kari \& Hartel, 2007, p. 1131) such as nature and function religious information in an everyday religious context. In an effort to bridge these two significant gaps, this study seeks to identify the everyday life religious information practices of Buddhists, particularly those of the New Kadampa Tradition of Buddhism.

\section{Methodology}

\section{Research Questions}

The study's research aims are: (1) to compile a list of the religious information practices of Kadampa Buddhists; (2) to examine if there are religious or existential motivations for engaging in these religious information practices; (3) to understand the role of information in the attainment of spiritual realizations; and (4) to test the boundaries of ELIS. This preliminary report of findings primarily relates results from the latter three research aims. In particular, this report will highlight experiences of a duality between immanence and transcendence in the motivations for engaging in religious information practices, and in the use of religious information practices by my study participants. In addition, this preliminary report will briefly discuss this duality in the conceptualization of ELIS in light of these findings.

\section{Research Methodology}

This study was conducted within a naturalistic framework (Guba \& Lincoln, 1982) and was also conducted by a researcher who possesses 'insider status' within the community of study. Twenty adults who self-identified as members of the New Kadampa Tradition from Canada, the United States and the United Kingdom were recruited via several unofficial Kadampa Facebook groups, and in person at a 
local Kadampa meditation class, between May and August 2016. Using a grounded theory approach to data collection (Corbin \& Strauss, 1990), semi-structured interviews were conducted with the participants (four in person, sixteen via Skype or Facetime) about their Buddhist practice which lasted approximately thirty to ninety minutes. Interviews were transcribed and then analyzed with guidance from Corbin and Strauss (2008) using NVivo software.

\section{Findings}

\section{Dualities in Motivations for Religious Information Practices}

When taken as a whole, participants in the interviews noted several dualities which seemed to characterize the dual nature of religion mentioned in the introduction. First, participants noted immanent motivations for seeking religious information (e.g. to relieve personal suffering, find new source of satisfaction) but also transcendent motivations (e.g. to become a Buddha, gain spiritual realizations). Second, participants often expressed the single transcendent desire to find the meaning of life in the face of death, but were simultaneously motivated by the immanent goals of manifesting this meaning through searching for particular Dharma teachings. Third, participants noted that an immanent motivation for seeking religious information was to end their personal suffering but simultaneously demonstrated a motivation to go beyond that to free other beings from their suffering as well.

\section{Dualities in Religious Information Use}

Dharma can be understood in two main ways (Gyatso, 2013). The Dharmas of Scripture are the textual and oral teachings of Buddhism and the Dharmas of Realization are the complete internalization and stabilization of these teachings within the mind of an individual that functions to prevent suffering. Participants described their use of these two Dharmas in their experiences of information use. Participants demonstrated using the Dharmas of Scripture when they read Dharma books, listened to oral teachings at Kadampa centres, memorized teachings, or recited scriptures as part of a sadhana. Conversely, participants demonstrated using the Dharmas of Realization when they indicated they were using the experience of their Guru at their heart as a source of information (the Guru being an epitome of realization), and in their experiences of not merely using the Dharma, but in their experiences of transformation - of "being the Dharma". In other words, immanent information use was consistent with the use of the Dharmas of Scripture while transcendent information use with the Dharmas of Realization.

\section{Beyond Everyday Life Information Seeking?}

Clemens (2015) theorizes that information practices that are deeply meaningful, unfamiliar, extraordinary or profoundly emotional (p. 9) cannot be characterized as "everyday" because they no longer meet Savolainen's criteria for "everyday life" information practices. This study also seeks to examine the boundaries of ELIS. In this study, participants engaged in religious information practices as part of their everyday routines yet also noted the transcendent in their experiences: (1) that their understandings of their present situation was dictated by actions in a previous life and were leading to a future life; (2) that these practices "were not ordinary"; (3) and while they praised the benefits of their meditation practice and experiences of inner peace, their responses were often caveated with indications that they were not perfect, that their 
experiences were subtle, and gradual over time. In these cases, the everyday and the transcendent were both present.

\section{Discussion}

Religious information practices, at least in a Buddhist context, seem to have immanent and transcendent characteristics. These dualities will be explored further through the use of Buddhist philosophy and psychology, as well as Heidegger's ontological hermeneutics, to see if these theories provide some explanation to this seeming dichotomy. It is hoped that this research will be helpful in bringing light to new forms of information and in legitimizing the use of religious epistemologies in library and information science research and practice.

\section{Reference List:}

Clemens, R. A. (2015). Human information behavior, coping and decision-making in the context of a personal crisis: An interpretative phenomenological analysis of the voices of birthmothers on relinquishing a child for adoption (Unpublished doctoral dissertation proposal). University of North Carolina at Chapel Hill, Chapel Hill, North Carolina.

Corbin, J., \& Strauss, A. (1990). Grounded theory research: Procedures, canons, and evaluative criteria. Qualitative Sociology, 13(1), 3-21.

Corbin, J., \& Strauss, A. (2008). Basics of qualitative research, third edition. Thousand Oaks, CA: Sage.

Emmons, R. A. (1999). The psychology of ultimate concerns. New York: The Guilford Press.

Guba, E., \& Lincoln, Y. S. (1982). Epistemological and methodological bases of naturalistic inquiry. Educational Communication and Technology, 30(4), 233252.

Gyatso, Geshe K. (2013). How to understand the mind: The nature and power of the mind. Ulverston, England: Tharpa.

Kari, J. (2001). Information seeking and interest in the paranormal: Towards a process model of information action (Unpublished doctoral dissertation). University of Tampere, Tampere, Finland.

Kari, J. (2009). Informational uses of spiritual information: An analysis of messages reportedly transmitted by extraphysical means. Journal of Information Science, 35(4), 453-468.

Kari, J. (2011). Outcomes of information: An analysis of spiritual messages. The Open Information Science Journal, 3, 63-75. 
Kari, J., \& Hartel, J. (2007). Information and higher things in life: Addressing the pleasurable and the profound in information science. Journal of the American Society of Information Science and Technology, 58(8), 1131-1147.

Lambert, J. D. (2010). The information-seeking habits of Baptist ministers. Journal of Religious and Theological Information, 9(1-2), 1-19.

Michels, D. H. (2011, June 4). Beyond belief: Prayers as communication in religious information seeking. Available at SSRN: http://ssrn.com/abstract=2133494.

Michels, D. H. (2012). Seeking God's Will: The experience of information seeking by leaders of a church in transition. Canadian Journal of Information and Library Science, 36(1-2), 16-27.

Phillips, R. L. (1992). The relationship between work roles and information seeking behaviours among selected Protestant ministers in Tarrant County, Texas (Unpublished doctoral dissertation). University of North Texas, Denton, TX.

Porcella, B. (1973). The information gathering habits of Protestant ministers of Cedar Rapids, Iowa (Unpublished doctoral dissertation). University of Illinois at Urbana-Champaign, Champaign, IL.

Roland, D. R. (2007). Interpreting scripture in contemporary times: A study of clergy member's sense-making behavior in preparing the Sunday sermon (Unpublished doctoral dissertation). Emporia State University, Emporia, KS.

Saleh, A. G., \& Abu Bakar, A. B. (2013). Information-seeking behaviour of the Ulama in relation to preaching and counseling roles in Nigeria. Theological Librarianship, 6(1), 29-46.

Savolainen, R. (2004). Everyday life information seeking. Encyclopedia of Library and Information Science (pp. 99-129). New York, NY: Dekker Encyclopedia.

Tanner, T. M. (1994). What ministers know: A qualitative study of pastors as information professionals. Metuchen, NJ: Scarecrow Press.

Wicks, D. A. (1999). The information-seeking behavior of pastoral clergy: A study of the interaction of their work worlds and work roles. Library and Information Science Research, 21(2), 205-226. 